Article

\title{
Does Structural Capital Affect SDGs Risk-Related Disclosure Quality? An Empirical Investigation of Italian Large Listed Companies
}

\author{
Francesco De Luca ${ }^{1, * \mathbb{D}}$, Andrea Cardoni ${ }^{2}$, Ho-Tan-Phat Phan ${ }^{3}$ and Evgeniia Kiseleva ${ }^{2}$ \\ 1 Department of Management and Business Administration, University “G. d'Annunzio" of Chieti-Pescara, \\ 65127 Pescara, Italy \\ 2 Department of Economics, University of Perugia, 06123 Perugia, Italy; andrea.cardoni@unipg.it (A.C.); \\ evgeniia.kiseleva@studenti.unipg.it (E.K.) \\ 3 Department of Accounting and Finance, Collat School of Business, University of Alabama at Birmingham \\ UAB, Birmingham, AL 35294-4460, USA; phanho@uab.edu \\ * Correspondence: francesco.deluca@unich.it
}

Received: 25 January 2020; Accepted: 25 February 2020; Published: 27 February 2020

\begin{abstract}
In a context of widespread acceptance and implementation of the United Nations Sustainable Development Goals (SDGs), this paper discusses the possible relationship between intellectual capital (IC) and nonfinancial information (NFI), particularly related to SDGs and corporate social responsibility (CSR) in a stakeholder engagement perspective. Prior studies called for further investigation about nonfinancial risk disclosure and claimed that companies mandated to disclose risk-related information tend to focus mainly on financial risks. Therefore, given the growing attention of regulators to the content of mandatory companies' NFI brought to the Directive 2014/95/EU, this study intends to contribute to fill this literature gap by investigating the drivers of risk-related disclosure quality (RDQ) and to what extent it could be affected by the structural capital (SC), as one of the components of IC. The empirical analysis is based on a sample made of 51 Italian large undertakings and groups. The study uses content analysis to assess the RDQ from firms' corporate reports. Regression analysis is used to examine if there is an influence of SC toward RDQ, both considered as a single information package and with specific reference to environmental disclosure. Results reveal that a positive association exists between RDQ and SC. Moreover, it is providing some support for the positive correlation between SC and the firm's size. In this sense, the paper contributes to existing risk reporting literature as a pioneering study identifying an IC driver to determine the quality of risk and risk management information. For regulators, this study highlights how, in a context of mandatory disclosure, the quality of information could also depend on firm characteristics (SC). For practitioners, the paper helps in understanding the role of IC in order to increase the quality of the corporate risk reporting.
\end{abstract}

Keywords: SDGs; CSR; nonfinancial information; risk-related disclosure; Directive 95/2014/EU; intellectual capital; structural capital; stakeholder engagement; Italy

\section{Introduction}

Within corporate settings, risk identification and risk management processes have been under a constant spotlight in recent years. A decade after the global financial crisis, the uncertainties in the economy have shaped the way corporates behave in facing and policing risk and risk management. Every business could face the risks of unexpected events, such as natural disasters, market and industrial instabilities, unrealistic strategies, production interruptions, injuries, and many others. Corporate activities risks affect climate change issues and might harm the surrounding environment and society. 
Particularly, "bigger" risks affect the so-called wicked problems in light of their pervasiveness for humankind and difficulties to solve [1,2]. Any of these events can cost not only firms' money and reputation but also the harmony of the natural world around the organization.

In this context, the United Nations Global Compact [3], along with the seventeen UN Sustainable Development Goals (SDGs) [4], called companies to align strategies and operations with universal principles on human rights, labor, environment, and anti-corruption and take actions that advance societal goals.

At the same time, with the expanding extent of corporate's uncertainties, investors and other stakeholders (users of companies' reports) are paying more and more attention in information about risks related to corporate social responsibility (CSR) and environmental management. The regulatory pressures for improved risk assessment and reporting on internal control have increased around the world and more so after the establishment of the SDGs. The reason is that corporate accounting failures, frauds, internal control breaches, governance failures, scandals, and polluting accidents have been experienced by companies and countries even though they are thought to be (or pretend to be) immune to these events. The unexpected successive failures of large corporations, also due to nonfinancial reasons, that were previously considered as low-risk profiles, raise the question about the scope and the relevance of this information. This situation is pushing policymakers to take actions to improve the quality of corporate disclosure. For example, pressures resulting from the UN's SDGs are provoking an increase in risk disclosure relating to the CSR risks, such as environmental, social, and sustainability issues [5]. The European Union also has further confirmed its commitment in the sustainable development [6] and the recent directive 2014/95/EU directing large companies to disclose several nonfinancial information that has been implemented in Italy by Legislative Decree No. 254 of December 30, 2016. These initiatives are intended to mandate large companies to identify and disclose their principal risks and related policies to increase trust among investors and stakeholders [7].

Generally, investors and stakeholders pay much attention to the information that demonstrates how management is handling tough or risky scenarios, because the information on risk factors helps them to better understand what the consequences of the company's performance are if particular risks materialize $[8,9]$.

In fact, in the investors' perspectives, CSR activities have been investigated in their relationship with financial performance [10] and access to finance [11]. CSR reports have also been put in relationships with stakeholder engagement and forecast accuracy by financial analysts: García-Sánchez et al. [12] found evidence about how the joint use of global reporting initiative (GRI) guidelines, and the International Finance Corporation (IFC) performance standards (defined as GRI-IFC disclosure strategy) has a positive impact on the accuracy of analysts' forecasts. Moreover, several studies across countries find evidence that risk information is significantly useful in the financial market. With a sample of 9076 observations of US firms-years from 2005 to 2008-Campbell et al. [13] found that risk information is firm-specific and useful to investors due to the significant association between the risk information with market value and risk levels. In the same vein, Elshandidy and Neri [14] studied a sample of nonfinancial firms in the UK and Italy and found that voluntary information disclosed by strongly governed firms significantly improves market liquidity. The same notion appears in the paper by Elshandidy and Shrives [15]. They revealed that the German market tends to react according to the risk-related information, either by improving or worsening market liquidity or by decreasing or increasing investor-perceived risk. A similar study from a sample of the Middle East and North Africa emerging markets, conducted by Moumen et al. [16], demonstrates a positive relationship between voluntary risk information and the market's ability to anticipate two years ahead future earnings changes.

In a wider stakeholders' perspective and engagement, instead, the turning point for the development of sustainability disclosure was the issuing of the GRI guidelines, which pushed NFI disclosure practices from a spot phenomenon to a systematic activity involving strategic aspects such as corporate risk and opportunities, anti-corruption, corporate governance, and fraud matters 
management [17]. By following GRI guidelines, disclosing organizations provided their stakeholders with reliable, important, and standardized NFI [18]. Therefore, recent policy changes in sustainability reporting, such as the ones related to the new European directive on nonfinancial disclosure (2014/95/EU), the standards issued by the American Sustainability Accounting Standard Board (SASB), the G4 guidelines issued by the Global Sustainability Standard Board (GSSB), and the framework of the International Integrated Reporting Council (IIRC), highlight the importance of extending the disclosure of ethical, social, and environmental risks within financial and social-environmental reporting [5].

The above studies suggest that risk-related information is essential and desired by investors and other stakeholders. Moreover, the evolution from mainly voluntary to mandatory information has increased pressure for organizations to set up risk management tools to understand sustainability risks within managerial and reporting practices. Therefore, it is generally agreed that there is substantial demand for a better risk-related disclosure quality [19].

Prior studies have also investigated the reasons that push companies into disclosing NFI. They are mainly framed within the legitimacy theory, according to which companies disclose to legitimate themselves towards society, providing evidence that they operate within the boundaries established by society $[20,21]$. As for the relationship between the EU directive and GRI standards, it can be affirmed that both consider the disclosure of NFI separately from financial information, and both are stakeholder-oriented. Conversely, the GRI framework appears to be more demanding than the EU directive, containing a long list of requirements that preparers have to fulfil [22].

Several studies supported the hypothesis that companies limit the voluntary disclosure of information to the financial market because of the existence of disclosure related to proprietary costs. Roulstone [23] found the variation in the amount of financial risk disclosure across firms and also evidence of deficient firm-specific information on risks. Abraham and Shrives [24] found similar evidence for the argument that company managers prefer providing symbolic disclosures on risks, even though specific risk information had been proven to enable analysts to better assess firms' fundamental risk analyses. Hope et al. [25] quantified the firms' levels of specificity to examine the informativeness of risk information, and they also found a low proportion of specific risk disclosure. Given that real benefits of CSR arise only if it is embedded within an organization, in its strategy, operations, and routines [26], there is a growing criticism asserting that NFI is utilized primarily as an impression management tool. Such findings highlight that CSR/sustainability disclosure can be used as a legitimacy tool [26], even disconnected from sustainability action or performance and/or dictated by specific institutional pressures [27], where also country level differences may affect the disclosure policy [28]. Generally, it is visible that policymakers are progressively pursuing improved and mandated risk information, and this means that its quality of is not adequate yet for investors and other stakeholders to evaluate the business. Hence, in order to improve the practice and to provide policymakers with some useful evidence, it is crucial to investigate what are the drivers of risk disclosure quality of firms.

The recent study of Truant et al. [5] that has been still run in a context of voluntary disclosure provides evidence of the fact that "experienced" sustainable reporters provide a significant volume of disclosure and that disclosure quality on risk is positively influenced by their international presence and reporting experience. However, in the case of accounting for specific risk-related areas of disclosure, only a few of them seem to adopt a managerial perspective linking strategy, risk metrics, and disclosure. Beside some past studies that pinpoint the key determinants of the corporate's risk disclosure quality, such as firm characteristics and corporate governance, in this paper, a new point of view is addressed by introducing intellectual capital (IC) as a key factor that influences the overall quality of risk disclosure in a context of mandatory reporting contents. In fact, some previous studies already investigated the possible relationship between CSR and IC, but they prevalently intended this relationship as unidirectional, namely from CSR to IC [26]. Conversely, in this study, the RDQ is deemed to be driven by a good process of risk identification and management, as well as a reporting process. These processes are the structural capital of the firm. Consistently with the previous recent studies' definition of IC and 
its components [29,30], SC is considered as one of the three primary components of intellectual capital, which consists of the supportive infrastructure, processes, and databases of the organization that enable human capital to function. Moreover, with reference to the resource-based view managerial framework, firms with high levels of IC performance are expected to have better preparation to withstand and even exploit the effects of uncertainties. Indeed, IC is leveraged to reduce the perceived risks by educating the stakeholders' perceptions of risks and the company's policies to manage those risks. In the same vein, this empirical research aims to investigate whether firms with a higher level of structural capital (SC) have better disclosure on risk and risk management policies.

Therefore, the objective of this study is to examine the relationship between SC and RDQ. To this end, the study analyzes disclosure quality on a sample made of 51 large undertakings and groups which are subjected to the Legislative Decree No. 254 of December 30, 2016. First, based on prior literature and regulation guidelines, a detailed framework that consists of six types of risk is developed. Next, from the framework, the study assesses the quality of disclosure in three aspects, namely, the level of specificity, time orientation, and type of information. OLS regression analysis is also used for the empirical analysis. The dependent variable is the RDQ, while the independent variable is SC, which is calculated by the value-added intellectual coefficient (VAIC) method [31,32] and a set of control variables indicating firm characteristics in firms' corporate governance.

The results reveal that RDQ is positively influenced by SC. There is also some evidence of a positive correlation between firms' sizes and SC. Accordingly, these results provide some contributions to both existing risks reporting literature and practitioners. Firstly, the study identifies a new driver to determine RDQ. Secondly, the findings of this study provide some insights to the management board of both large undertakings and groups and small and medium-sized enterprises (SMEs) for the sake of improving their disclosure practice.

The remainder of the paper proceeds as follows. The next section provides a brief review of the literature about the determinants of risk disclosure and describes the theoretical framework adopted to address the research questions. Section 3 describes the data and statistical methodology used in the empirical analysis. In Section 4, empirical results are reported and discussed. Finally, Section 5 provides some concluding remarks and implications of the study.

\section{Analytical Framework}

\subsection{Prior Literature on the Determinants of Risk-Related Disclosure Quality}

Over time, corporate disclosures have progressively added social and environmental risks beside the solely financial risk disclosure [33], and previous studies on risk disclosure and reporting have observed this phenomenon from several perspectives and according to different theoretical frameworks.

Risk disclosure has been defined by previous studies as information about any opportunity, danger, threat, or exposure that has or could impact the company in the future [34].

With a normative approach, Beretta and Bozzolan [35] proposed a framework for the analysis of risk communication and an index to measure the quality of risk disclosure and applied this framework to a sample of nonfinancial companies listed in the ordinary market of the Italian Stock Exchange. They specifically focused on the quality of disclosure and the richness of its contents rather than merely on its quantity. Their outcomes propose that the amount of risk disclosure is for the most part determined by firms' sizes, as opposed to industry type. In particular, the outcomes affirm that the relative quantity, density, and outlook are not factually affected by the size or the industry; however, they do appear to significantly affect the depth of the information. Similarly, Linsley and Shrives [36] used manual content analysis (number of sentences) in a sample of 79 Financial Times Stock Exchange (FTSE) 100 nonfinancial firms in year 2000 and found a significant association between risk disclosures and firm size and the level of environmental risk. They also pointed out that an absence of coherence in the risk narratives infers a risk information gap, and thus, stakeholders cannot sufficiently assess the risk profile of an organization. 
From a sample of 71 FTSE 100 nonfinancial firms in 2002, Abraham and Cox [37] found that corporate risk-reporting is negatively related to sharing ownership by long-term institutions (e.g., pension funds), and subsequently, the results infer that these institutional financial specialists prefer to invest in firms with a lower dimension of risk disclosure, where authors define the dimension as the number of words within risk-related sentences. Concerning corporate governance (CG), they suggest that the number of executives and the number of independent directors are positively related to the dimension of risk disclosure. Moreover, Al-Hadi, Hasan, and Habib [38] find that organizations with a separate risk committee are likely to disclose more market risk information than others. These organizations' decisions to disclose the information is also affected by the size and qualification of the committee.

Marshall and Weetman [39] constructed an index for risk disclosure from 80 nonfinancial (40 UK-based and 40 US-based) firms at 1998/99 and found that the information asymmetry gap in the UK is lower when gearing or liquidity is higher. Deumesa and Knechel [40] constructed an index for internal risk disclosure from 192 nonfinancial listed firms from 1997 to 1999 and found a negative relationship between the level of internal control disclosure and block-holder ownership and a positive relationship between the degree of risk information and financial leverage. In addition, the paper of Ntim, Lindop, and Thomas [41] finds that corporate risk disclosure is negatively related to block ownership and institutional ownership and positively related to board diversity, board size, and independent nonexecutive directors.

Particularly, an empirical study of FTSE 72 UK nonfinancial firms [42] outlined a synthetic list of driver factors of risk disclosure. The drivers are sorted into two groups, which are firm-specific characteristics and CG mechanisms. Respectively, firm characteristics comprise industry type, size, cross-listing, profitability, liquidity, and financial leverage, and CG is determined by institutional ownership, board size, role duality, board independence, and audit committee size. Consistently, with both agency and signaling theories, their results show that company size and type of business are positively associated with the risk disclosure level, where authors define level as the number of risk-related sentences. However, the other firm characteristics variables (profitability, liquidity, gearing, and cross-listing) and CG attributes (institutional ownership, role duality, board size, board composition, and audit committee size) appear not to have a significant relationship with the level of risk disclosure in interim reports.

However, past research mainly focused on the disclosure of financial risk in countries where the disclosure was mandatory [43], and the usefulness of risk disclosure for stakeholders, as well as the extent of risk disclosure, have been investigated mainly with reference to financial risks $[36,44,45]$ and its usefulness for investors $[35,46]$. On the contrary, the disclosure of nonfinancial risks has been scarcely investigated [45], and only recently, theoretical and empirical studies have started to investigate sustainability risk disclosure [47]. Among nonfinancial risk areas, environmental risk has received the most attention from scholars [48,49], and it is also one of the most reported sustainability issues [50]. Among studies focused on nonfinancial risks disclosure in general terms, Dumay and Hossain [33] investigated the sustainability risk mandatory disclosure practices of listed companies in Australia and two studies based on the Italian context, one before the EU transposition introduced Decree No. 254/2016 [5] and one after this decree [43].

This study, instead, intends to focus specifically on the level of risk disclosure quality (RDQ) and on its determinants in order to depict the state-of-the-art of the disclosure of nonfinancial risks in the aftermath of the EU directive in the Italian context and to contribute to filling a recognized gap in academic research $[45,51,52]$. Generally, in fact, prior empirical studies provide evidence that risk-related disclosure is driven by two main sets of factors, namely, the firm characteristic and corporate governance. Therefore, to the best of our knowledge, earlier studies have paid less attention to intellectual capital as one of the determinants to drive risk-disclosing behavior of firms. 
2.2. The Development of the Hypothesis: The Role of Structural Capital in Rrisk-Related Disclosure Quality on the Legitimacy Theory and Resources-based Perspectives

As a matter of fact, the risk-related disclosure quality is driven by a good process of risk identification and risk management, as well as risk-reporting process. These processes are parts of the structural capital of the firm.

Structural capital is a crucial and critical element of intellectual capital. In most cases, specialists in the field have recognized three fundamental builds of intellectual capital that includes human capital, structural capital, and relational capital [53]. At present, this taxonomy is still preferred by researchers. In fact, by a systematic literature review based on empirical studies made between 1960 and 2016, [54] found that this triad formed of intellectual capital is the one most used by researchers.

With the existence of human and relational capital, a business can be kicked off. However, the business never grows up with just these two kinds of intellectual capital. This is because the leverage of intangible capital comes in the creation of structural capital - that is, the set of procedures, processes, and internal structures contributing to the implementation of the organization's goals [55]. Structural capital is the supplementary infrastructure that permits the corporation to operate in a repeatable and extensible manner. It includes organizational philosophy, techniques, procedures, programs, data, systems, and the like.

As also suggested by Bayraktaroglu, Calisir, F., and Baskak [32], the long-term survival of a firm and its performance relies also upon how it invests and improves its structural capital. The idea of structural capital has a variety of implications for an organization. These implications, whenever perceived and overseen appropriately, would make the company stronger in the long term, especially in turbulent economies. Moreover, Tahat et al. [56] identify several points to key omissions and deficiencies in the extant literature on risk-reporting that is largely dominated by the accounting standards for financial instruments issued by the FASB and the IASB. In this context, specifically, structural capital could play an essential role in addressing those deficiencies and enhancing the quality of corporate risk-related reporting [29]. Literally, successful enterprise risk management, as the process of analyzing the possibility of exposure to risk and determining the appropriate practices to handle such exposure, can avoid unnecessary difficulties or minimize unavoidable incidences in the future. Structural capital consists of intangible assets included in the company's organizational processes and procedures that facilitate the flow of identifying, managing, monitoring, and reporting the risks. It is also the skeleton of this study which intends to provide an empirical analysis to investigate whether firms with a higher level of structural capital have better disclosure quality on risk-related information in the aftermath of the decree issuance. In fact, consistently with the previous recent studies' definition of IC and its components [29,31], we consider SC as one of the three primary components of intellectual capital, which consists of the supportive infrastructure, processes, and databases of the organization that enable human capital to function.

This paper is adopting the rationales proposed by Oliveira, Rodrigues, and Craig [57] to develop the hypothesis on the perspectives of legitimacy theory and resources-based perspective.

The legitimacy theory is derived from a political legitimacy study, namely, "Basic concepts in Sociology" of a German economist and sociologist, Max Weber, in 1922. Later, in 1975, Dowling and Pfeffer [58] developed the concept of legal legitimacy in organizations, and this was the basis for the development of the legitimacy theory. The legitimacy theory posits that the organization's operations must respect the values and norms of the society where the organization operates. The fact that organizations do not comply with social values or norms may lead to difficulties for that organization in gaining community support to continue operating. A social contract expresses the desires of society, which can be explicitly or implicitly established between the organization and society. Compliance with the terms of the social contract helps the business achieve legitimacy in operations, which is therefore accepted by society and the community, as well as ensures the conditions for continued operation and vice versa. In short, Suchman [21] considers that "[1]egitimacy is a generalized perception or 
assumption that the actions of an entity are desirable, proper, or appropriate within some socially constructed system of norms, values, beliefs, and definitions."

In our conception, the legitimacy theory has the role of explaining the behavior of organizations in implementing two main legal frameworks, namely, (1) Art. 2428 of the Italian Civil Code by providing a description of the main risks and uncertainties the company is exposed to and (2) the new Italian Legislative Decree No. 254 of December 30, 2016 by disclosing the information about their principal sustainable risks. Moreover, this theory well explains the behavior of organizations in proactively disclosing not only mandatory but also voluntary information in order to fulfill their social contract, which enables recognition from society and increases the trust among investors and stakeholders.

In a complementary manner, the resource-based perspective proposes that a firm's distinctive competence is a "function of the resources which a firm possesses at any point in time" [59]. That is to say, firms are heterogeneous in light of the fact that they have heterogeneous resources, meaning firms can have different strategies because they have different resource mixes. As per the resource-based view, a company's ability to develop distinct resources and capabilities increases its ability to adapt to the changing competitive environment and improves its prospects for survival [60]. With reference to our concept, firms with high levels of structural capital are expected to have a better preparation to exploit, withstand the effects of uncertainties, and even better, in reporting their risks and risk-hedging policies. In point of fact, intellectual capital, particularly in the case of structural capital, is leveraged to reduce the perceived risks by educating the stakeholders' perceptions of risks and company policies to manage those risks. In the same vein, from a content analysis of the information provided in the management discussion and analysis section of the annual reports of 72 companies, Boesso and Kumar [61] documented that, in addition to investors' information needs, factors such as company emphasis on stakeholder management, relevance of intangible asset, and market complexity affect both the volume as well as the quality of voluntary disclosures. As also highlighted by Zaman Khan et al. [62], the investment in key intangible resources and capabilities of firms, including IC, together with financial capability and CSR, could have a positive impact on sustainable competitive advantage and firm performance. Based on these arguments, the research hypothesis is stated as follows:

Hypotheses 1. There exists a positive association between the structural capital and risk-related disclosure quality.

\section{Research Design}

\subsection{Sample}

This study intends to shed light on the mandatory disclosure in accordance with the recent Italian Legislative Decree No. 254 of December 30, 2016. Hence, we intentionally choose a sample of companies which are legally subjected to this decree. Pursuant to Section 2 of the decree and Section 16 of Legislative Decree No. 39/2010, the new disclosure requirements shall apply to public interest entities, which are defined as Italian companies meeting the following criteria: exceeding, on an individual or consolidated basis, (i) 500 employees on average during the relevant fiscal year, as well as (ii) at least one of the following thresholds: total net asset value of $€ 20,000,000$ or total net revenues from sales and services of $€ 40,000,000$ at the end of the relevant fiscal year. By using the AIDA (Bureau Van Dijk) database, the list of potential companies for the study has been composed. After considering only companies mandated to adopt the new rule and excluding banks and financial institutions that reports under different rules, AIDA provides a list of 65 listed companies following the aforementioned criteria. Then, nonfinancial reports are collected from those companies' websites. Finally, the research question is analyzed on a final sample of 51 companies with available data.

Other companies are dropped off the sample for two reasons. They are: (1) the publication dates of the report exceed the research timeline, and (2) the language used in the reports is not English. This sample size is quite adequate for further empirical inferences about a 65 -company population at $95 \%$ 
of confident level and $5 \%$ of margin of error. The following list summarizes the steps of the sample selection process:

- No. of Italian listed companies: 358,

- No. of nonfinancial-listed companies: 283,

- No. of nonfinancial-listed companies subjected to Legislative Decree 254: 65, and

- No. of nonfinancial-listed companies subjected to Legislative Decree 254 with available data: 51.

The Italian market provides an interesting field of research because of a series of law reforms that have been issued during the last decade, the last of which is related to the adoption of the aforementioned directive with Legislative Decree No. 254. With the new issuance of this law, we believe that the Italian case study will provide a significant view and insights about the disclosure practices in this new era of corporation disclosure. This new regulation is like a catalyst for corporates to take a step back and review the risk profiles which they are bearing. Hence, this is a good occasion to oversee their behavior in disclosing risk-related information.

\subsection{Method: Dependent Variable}

Risk disclosure is qualitatively presented in companies' annual reports, as well as in the other separate reports, such as the nonfinancial report and sustainability report. There are numerous approaches for analyzing qualitative data. Content analysis, as a method of analyzing written, verbal, or visual communication messages $[63,64]$, has been chosen to analyze the risk- related disclosure. Further statistical tests have been carried out to support the robustness and the reliability of our findings.

The coding scheme that is developed is the combination of both "expert" and "norm" [64]. The instruments of risk disclosure in this research are developed as the elements of the risk profile based on the previous study of Greco [65] (referring to "expert" from Potter and Levine-Donnerstein [64]) with the necessary adjustment following the more recent reform operated by Italian Law no. 254/2016 (referring to "norm" from Potter and Levine-Donnerstein [64]). This framework is adopted here, because it is offering an adequate submission of risk types with a high level of detail. To this end, environmental risk (energy resources, greenhouse gas emissions, and air pollution); social and employee risk (health and safety, gender equality, supranational and international organizations, and social dialogue), and corruption and bribery risk are added to the scheme.

Accordingly, a set of key concepts were constructed below to identify the focused information for 27 elements for six risk factors. The details are presented in Table 1 with six variables which represent six types of risk. 
Table 1. Types of Risks.

\begin{tabular}{|c|c|c|}
\hline Risk Factor & Elements & Description $[66,67]$ \\
\hline \multirow{5}{*}{ Strategic risks } & Macro-environmental & Macro environmental risk, classified to the level of country risk, includes political/legal, economic, social, demographic, technological, and the like. \\
\hline & Industrial & Industry risk refers to the uncertainty that stems from wide-ranging issues involving the entire industry that the company belongs to. \\
\hline & $\begin{array}{c}\text { Competitive } \\
\text { Business norffolio }\end{array}$ & 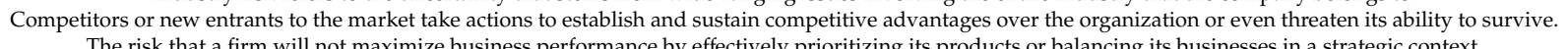 \\
\hline & Business portfolio & $\begin{array}{l}\text { The risk that a firm will not maximize business performance by effectively prioritizing its products or balancing its businesses in a strategic context. } \\
\text { ond }\end{array}$ \\
\hline & Planning & 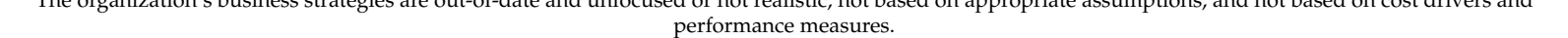 \\
\hline \multirow{5}{*}{ Reputation risks } & Product lifecycle & The risk threatens the ultimate success of its business strategies in managing the movement of its product lines and evolution of its industry along the life cycle. \\
\hline & Corporate image & $\begin{array}{l}\text { The risk that an organization may lose trust from customers and key employees or its ability to compete, due to perceptions that it does not deal fairly with customers, } \\
\text { suppliers, and stakeholders or know how to manage its business. }\end{array}$ \\
\hline & Business ethics & The organization, through its actions or inactions, demonstrates that it is not committed to ethical and responsible business behavior. \\
\hline & Customer satisfaction & The organization's processes do not consistently meet or exceed customer expectations. \\
\hline & Product development & The product development process is significantly weaker than more innovative competitors. \\
\hline \multirow[t]{3}{*}{ Operation risks } & Process management and Infrastructures & $\begin{array}{l}\text { The risk of the organization's capability to continue critical operations and processes due to the unavailability of certain raw materials, technologies, infrastructure, and } \\
\text { other resources. }\end{array}$ \\
\hline & HR management & The risks that the personnel does not possess the requisite knowledge, skills, and experience needed to ensure those critical business objectives. \\
\hline & Information systems & $\begin{array}{l}\text { The risk that the information technologies used in the business are not efficiently and effectively supporting the business or the risk of theft or damage to the hardware, } \\
\text { software, or data. }\end{array}$ \\
\hline \multirow{8}{*}{ Compliance risks } & $\begin{array}{l}\text { Stock obsolescence and shrinkage } \\
\text { Product and service failure }\end{array}$ & $\begin{array}{l}\text { The risk of the shortages of energy, other key commodities, and raw materials used in the operations. } \\
\text { The risk of faulty or nonperforming products or services. }\end{array}$ \\
\hline & Health and safety & $\begin{array}{l}\text { These risks of the likelihood that a person may be harmed or suffers adverse health effects due to not only the operational process but also the products and services } \\
\text { provided by the organization. }\end{array}$ \\
\hline & Environment & $\begin{array}{c}\text { Environmental risks of the liability to third parties for the damage caused by the pollution and the liability to governments or third parties for the cost of removing } \\
\text { pollutants plus severe punitive damages. }\end{array}$ \\
\hline & Industry regulation & $\begin{array}{l}\text { The risk that changes in regulations and actions by national or local regulators can significantly affect an organization's ability to efficiently conduct business, such as } \\
\text { antitrust and fair competition. }\end{array}$ \\
\hline & Social and employee-related matters & Failure to conform with laws and regulations at gender equality, supranational and international organizations, and social dialogue. \\
\hline & Law 231/2001 & Liability for crimes committed by a company's representatives. \\
\hline & Human rights & Risk of violations and discrimination in the workforce. \\
\hline & Corruption and Bribery & $\begin{array}{l}\text { Risk of offering, paying, or receiving a bribe through an officer, employee, subsidiary, intermediary, or any third party (individual or corporate) acting on the } \\
\text { commercial organization's behalf. }\end{array}$ \\
\hline \multirow[t]{2}{*}{ Reporting risks } & Financial accounting and reporting regulation & $\begin{array}{l}\text { The risk of the ineffectiveness of disclosure controls and procedures, resulting in material information not being disclosed timely to certifying officers and in public } \\
\text { reports. The risk of ppublishing material misstatements or omitting material facts, making them misleading. }\end{array}$ \\
\hline & Law 262/2005 & $\begin{array}{l}\text { Risks of inadequacy and ineffective application of the financial reporting procedures and that the accounting records are not able to provide a true and fair view of the } \\
\text { balance sheet, statement of income, and financial position. }\end{array}$ \\
\hline \multirow[b]{2}{*}{ Financial risks } & & The exposure to actual loss or opportunity cost as a result of default or other failures by the debtor. \\
\hline & $\begin{array}{l}\text { Market (interest rate, exchange rate, and market prices) } \\
\text { Liquidity }\end{array}$ & $\begin{array}{l}\text { The exposure of earnings or net worth to changes in market factors (e.g., interest rates and currency rates), which affect income, expense, or balance sheet values. } \\
\text { The exposure to loss as a result of the inability to meet cash flow obligations in a timely and cost-effective manner. }\end{array}$ \\
\hline
\end{tabular}


In order to qualify the information, relative scores were assigned to the nature of the information disclosed. According to Guthrie and Parker [68], a disclosure statement should be on both "what was said and how it was said". Therefore, many researchers had gone beyond only counting the number of disclosures made; they have assigned scores to weigh the information based on the nature of the information disclosed $[35,61,69,70]$. Using scores to calibrate the information is theoretically justified, and numerous researchers have recommended such an approach. This paper follows the same line of thought.

Firstly, Hope et al. [25] identified specificity (e.g., information containing the names of persons, locations, and organizations; quantifications of risk, such as values in percentages and money values in dollars; and chronological information, such as times and dates) as a measurement of the disclosure. In the same vein, Abraham and Shrives [24] also suggest that disclosures should be company-specific-concerned rather than be general or industry-specific. Thus, it seems appropriate to award a higher score for more specific information. Similarly, Guthrie and Petty [71] have argued that what is lacking in voluntary disclosures is the company's attempt to translate discursive into numerical measures. For this reason, quantitative disclosures are in favor, and higher scores can be assigned to them [31,56]. Finally, Hooks et al. [72] and Lev and Zarowin [73] mentioned the importance, as well as the increased interest, in corporate reporting to express the forward-looking information. As such, information projected into the future can be given a greater score than historical information [35,61].

In the end, in a similar way to Beretta and Bozzolan [35] and Boesso and Kumar [61], the quality of the information is approximated as a linear combination of the aforementioned dimensions. In this spot, of course, the analysis shares the same limitations of this assumption with other similar studies.

Practically, this paper uses three phases to score each disclosure. The first two phases study the level of specificity; the last phase studies the time orientation and type of information.

In detail, phase 1 implemented content analysis-based disclosure checklists which are designed to measure whether or not an item is disclosed [74]. The study involved reading the risk and risk management sections in the management reports (commentary), consolidated nonfinancial reports, sustainability reports, and notes on financial risks of the sample companies and checking if an element in the risk factor was reported or not. As can be seen, this is simply a yes/no checklist of items that may or may not be disclosed. Moreover, it is recorded whether the information is a risk description or a risk management policy.

Phase 2 used the dichotomous coding approach that is developed according to the following scale, as suggested by [24], which is aimed to measure the level of specificity of information disclosed by the companies. Every element taken from phase 1 of the analysis is categorized into four levels, which are (0) no disclosure, (1) general disclosure, (2) industry specific disclosure, or (3) company-specific disclosure. To measure the specificity level of the risk description information of risk type $\mathrm{j}$ of company $i$, the index presented in Equation (1) is proposed. Moreover, Equation (2) measures the counterpart for the risk management information of risk type $j$ of company $i$. The following list summarizes the abbreviations used in Equations (1)-(6).

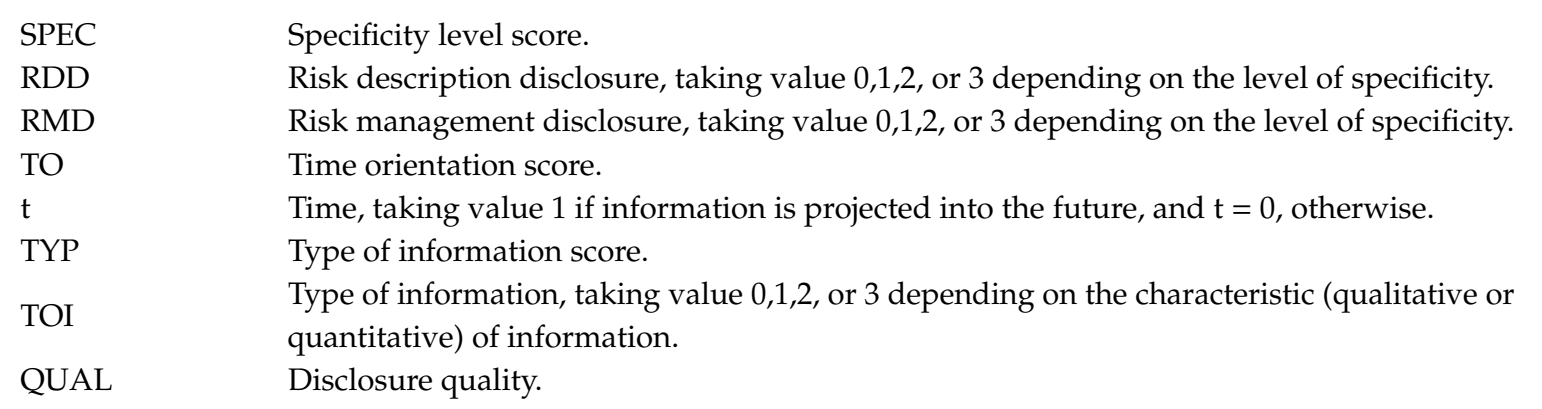

$$
S P E C_{R D}^{i j}=\frac{1}{k_{j}} \sum_{e=1}^{k_{j}} R D D_{e}^{i j}
$$




$$
\operatorname{SPEC}_{R M}^{i j}=\frac{1}{k_{j}} \sum_{e=1}^{k_{j}} R M D_{e}^{i j}
$$

where $k_{j}$ is the number of risk elements of risk type j. For risk description disclosure, $R D D=0$ if the information is not disclosed, $R D D=1$ if the information is generally disclosed, $R D D=2$ if the information is industry-specific disclosed, or $R D D=3$ if the information is company-specific disclosed. Similarly, for risk management information, $R M D=0$ if the information is not disclosed, $R M D=1$ if the information is generally disclosed, $R M D=2$ if the information is industry-specific disclosed, or $R M D=3$ if the information is company-specific disclosed.

Phase 3 measures the other two dimensions of the disclosed information, namely, time orientation and type of information. For each type of risk j in company i, Equations (3) and (4) are proposed to measure the time orientation and type of information, respectively.

$$
\begin{gathered}
T O^{i j}=\frac{1}{k_{j}} \sum_{e=1}^{k_{j}} t_{e}^{i j} \\
T Y P^{i j}=\frac{1}{k_{j}} \sum_{e=1}^{k_{j}} \operatorname{TOI}_{e}^{i j}
\end{gathered}
$$

where $k_{j}$ is the number of risk elements of risk type j. $\mathrm{t}=1$ if the disclosure includes a piece of information projected into the future, and $t=0$, otherwise. TOI $=3$ if the information is disclosed both qualitatively or quantitatively, TOI $=2$ if the information is disclosed quantitatively, $T O I=3$ if the information is disclosed qualitatively, or TOI $=0$ if the information is not disclosed. It is worth noting here that in the case of both $S P E C_{R D}^{i j}=0$ and $S P E C_{R M}^{i j}=0, T O^{i j}=0$ and $T Y P^{i j}=0$ are set.

Then, the quality index is computed for each type of risk $j$ in company $i$ by Equation (5), and finally, the ultimate disclosure quality of company $i$ is measured from six types of risks by Equation (6).

$$
\begin{gathered}
Q U A L^{i j}=\left\{\begin{array}{c}
0, \text { if } S P E C_{R D}^{i j}=0 \text { and } S P E C_{R M}^{i j}=0 \\
S P E C_{R D}^{i j}+S P E C_{R M}^{i j}+T O^{i j}+T Y P^{i j}, \text { otherwise }
\end{array}\right. \\
Q U A L^{i}=\frac{1}{6} \sum_{j=1}^{6} Q U A L^{i j}
\end{gathered}
$$

This study conducted the reliability test of the coding results from two independent coders. The reproducibility of the content analysis was assessed by the Krippendorff alpha of 0.88 , which showed a high degree of agreement among coders

\subsection{Method: Independent Variables}

In this paper, the value added intellectual coefficient (VAIC) method developed by Pulic [31] and Bayraktaroglu et al. [32] is used to measure the structural capital, because his model assigns explicit economic values to human capital (HC) and structural capital (SC) in order to generate a VAIC index. The VAIC is also often adopted to investigate the performance of individual companies. The VAIC model measures the extent to which an enterprise generates value added on the basis of intellectual resources.

Pulic established IC concepts in the realm of company economics. His model assigns explicit economic values, value added (VA) and capital employed (CE), to human capital (HC) and structural capital (SC), and on this basis, generates an unambiguous VAIC index. Since the measurement is derived from economic values such as VA and CE, of course, these measurements are potentially related to firm size. 
According to the model, in order to measure structural capital (SC), it is necessary to determine the value added (VA) to a company and its human capital (HC). The value added (VA) to a company is computed from the company operating profit factored in the personnel costs consisting of salaries and social costs and total depreciation, amortization, and write-downs in a company's long-term and current assets. The human capital (HC) of a company is also estimated by the human resources costs, which are calculated from overall wages and salaries expenditure. Finally, the structural capital (SC) is equal to the difference between the company's value added (VA) and its human capital (HC).

As discussed earlier in prior literature about the determinants of risk-related disclosure quality, previous empirical studies provide evidence that risk-related disclosure is driven by two main sets of factors, which are the firm characteristic and the corporate governance. Hence, variable size and industry indicate firm characteristics and duality and the proportion of independent directors indicate that the corporate governance has been factored in the model. To this end, the hypothesis is tested by executing the multiple regressions on the following model.

$$
\mathrm{QUAL}=\beta \_0+\beta \_1 \times \mathrm{SC}+\beta \_2 \times \mathrm{SIZE}+\beta \_3 \times \mathrm{INDUSTRY}+\beta \_3 \times \mathrm{DUALITY}+\beta \_4 \times \mathrm{INDP}+\varepsilon
$$

where QUAL is the log transformation of the risk-related disclosure quality (log transformation executed to meet the normality assumptions of the linear regression), SC is the standardized structural capital, and SIZE is the firm's size estimated by the standardized firm's market value. In order to avoid big differences in the scale with other variables, the proportion of maximum scaling ("POMS") method [75] is used. It allows to transform each scale to a metric from 0 (= minimal possible) to $1(=$ maximum possible $)$. POMS $=(($ observed - minimum $) /($ maximum - minimum $))$. DUALITY equals 1 when the CEO also holds the position of the chairman of the board, and DUALITY equals 0 , otherwise. INDUSTRY equals 1 if the firm is the manufacturing company, and INDUSTRY equals 0 , otherwise. INDP is the proportion of the total number of independent directors in the total number of directors and managers, and $\varepsilon$ is the error term.

To ensure the reliability of the data, this study conducted the reliability test of the coding results from two independent coders. This addressed the accuracy of the inter-observer standpoint. The reproducibility of the content analysis was assessed by calculating the Krippendorff alpha after the two coders independently completed the entire coding. The alpha level for coding was 0.88 , which showed a high degree of agreement among coders.

The variables are winsorized prior to the test to reduce the effects of possibly spurious outliers.

\section{Summary of Content Analysis and Descriptive Statistics}

Details on the descriptive statistics of the disclosure quality in each type of risk are presented in Table 2. It is of interest to note that financial risks have the highest mean among others (7.386 \pm 1.383$)$, followed by compliance risks ( $3.675 \pm 1.399)$.

Table 2. Descriptive Statistics of disclosure quality (QUAL).

\begin{tabular}{cccccc}
\hline QUAL & N & Minimum & Maximum & Mean & Std. Deviation \\
\hline Strategic risks & 51 & 0.000 & 4.500 & 1.971 & 1.303 \\
Reputation risks & 51 & 0.000 & 7.000 & 1.716 & 1.733 \\
Operation risks & 51 & 0.290 & 5.000 & 2.185 & 1.257 \\
Compliance risks & 51 & 1.000 & 7.000 & 3.675 & 1.399 \\
Reporting risks & 51 & 0.000 & 4.500 & 0.343 & 0.886 \\
Financial risks & 51 & 3.000 & 9.330 & 7.386 & 1.383 \\
\hline
\end{tabular}

Companies paid more attention to disclosing financial risks, which comprised credit risk, market risks, and liquidity risk. This is due to the adequate scheme and typology for the risks required by the IFRS. All companies disclosed information on credit risk. There is only one observation that was 
completely missing information on market and liquidity risks, while in other cases, some firms at least disclosed that they do not have at all or do not have significant exposure to a certain type of risk.

Within the scheme provided by Legislative Decree No. 254, compliance risks are in the second position of the top-highest quality of disclosures. Companies paid more attention to disclosing compliance risks, which comprised several elements of principal sustainability risks, such as environment, health and safety, social and employee-related matters, human rights, and corruption and bribery. This result can be explained by the good compliance practice of the companies with the new decree.

Operational risk is in the third position in the ranking list for the mean of the disclosure quality $(2.185 \pm 1.257)$. Within this type, companies are likely to report their uncertainties in process management and human resource management. The disclosure of stock obsolescence and shrinkage risks remains the lowest among all types of operational risks.

The mean of the strategic risk's disclosure quality is $1.971 \pm 1.303$. Firms tend to provide more information on macro-environment uncertainties. On the other hand, there is only one observation of product lifecycle risk. It could be mainly due to the fact that the fashion industry, in which they are operating, is cyclical (Luxottica S.p.A.). Historically, this industry has been cyclical, fluctuating with economic cycles, customer preferences, and other factors that affect consumer spending habits. However, this kind of information is either quite sensitive to the market or just not material; thus, very few companies decided to disclose this type of risk.

Reputation risks have a quite low quality of disclosure compared to others $(1.716 \pm 1.733)$. In short, companies consider that reputation damage entails the risk of harming relationships with their stakeholders, such as investors (e.g., Eni S.p.A.); customers (e.g., La Doria S.p.A); grantors and licensors (e.g., Autogrill S.p.A.); and local communities (e.g., Parmalat S.p.A).

About the reporting risk, as the lowest quality of disclosure among all types $(0.343 \pm 0.886)$, firms mainly consider it as the risks associated with noncompliance with the rules governing the listing of securities on the Stock Exchange of other countries (e.g., Prada S.p.A.); risks associated with related party transactions (e.g., Servizi Italia S.p.A.); risks associated with the consolidation of different subsidiaries' statements (e.g., Eni S.p.A.); or the risks of implementing the new financial reporting software (e.g., Brembo S.p.A.).

Additionally, in total, there are 23 manufacturing firms and 28 nonmanufacturing firms. Of these, 16 firms have duality leadership. On average, overall, firms have $6.67 \%$ of independent directors in the total number of directors and managers.

As part of the regression analysis, correlation coefficients are examined to assess the relative relationship among independent variables. The magnitude of the coefficients is considered, and the statistical significance of the coefficients is tested as well. A correlation matrix is provided in Table 3 showing correlation coefficients between independent variables. In this correlation matrix, there is a very strong correlation -0.928 between SC and size. This is a sign of the existence of multicollinearity.

Thus, in order to increase the robustness, the multicollinearity test has been conducted, and no multicollinearity problem has been found within the model.

Table 3. Correlation matrix of independent variables.

\begin{tabular}{lllllll}
\hline & & SC & Size & Industry & Duality & Independent Board \\
\hline SC & Pearson Correlation & 1 & $0.507^{* * *}$ & $-0.305^{*}$ & -0.275 & -0.182 \\
\multirow{5}{*}{ Size } & Sig. (two-tailed) & & $1.49 \times 10^{-2}$ & 0.02955 & 0.05119 & 0.2017 \\
& Pearson Correlation & & 1 & -0.242 & -0.238 & -0.149 \\
Industry & Sig. (two-tailed) & & 0.08718 & 0.09227 & 0.2976 \\
& Pearson Correlation & & 1 & $0.321^{*}$ & 0.123 \\
Duality & Sig. (two-tailed) & & & 0.02147 & 0.3915 \\
\multirow{2}{*}{ Independent Board } & Pearson Correlation & & & -0.006 \\
& Sig. (two-tailed) & Pearson Correlation & & & 0.9682 \\
& Sig. (two-tailed) & & & 1 \\
\hline
\end{tabular}

Significant codes: $0, * * * 0.001$, and ${ }^{*} 0.05$. 
To support our assumption of linear combination in the dependent variable, the linearity test is executed. The results reveal that $S P E C_{R D}, S P E C_{R M}, T O$, and TYP are significantly and positively associated with the QUAL for each type of risks.

\section{Discussion}

The regression model was assessed for the linear model assumptions using the global test [76] on four degrees-of-freedom at the level of significance of 0.05 . A list containing all of the assumptions is provided in Table 4 . The results report that all of the assumptions concerning the appropriateness of the linear model are met.

Table 4. Assessment of the linear model assumptions.

\begin{tabular}{cccc}
\hline & Value & $p$-value & Decision \\
\hline Global Test Statistic & 2.62245 & 0.6229 & Assumptions acceptable \\
Skewness & 0.05849 & 0.8089 & Assumptions acceptable \\
Kurtosis & 1.98303 & 0.1591 & Assumptions acceptable \\
Link Function & 0.43592 & 0.5091 & Assumptions acceptable \\
Heteroscedasticity & 0.14501 & 0.7034 & Assumptions acceptable \\
\hline
\end{tabular}

The regression model is approaching significance at a $p$-value of 0.0684 . About the goodness of fit, an adjusted R-squared of 0.1092 indicates roughly $11 \%$ of the variation in the disclosure quality, which is explained by these independent variables. In this multiple regression model, the residual standard error is 0.1073 on 45 degrees of freedom.

The residuals, presented in the first part of the regression output in Table 5, are essentially the difference between the actual observed response values and the predicted response values by the model. The output breaks it down into five summary points. By the results, the symmetrical distribution across these points on the central value demonstrates that the model fits the data very well. In other words, the model predicts certain points that fall pretty close to the actual observed points.

Table 5. Results of the regression model.

\begin{tabular}{ccccc}
\hline Residuals: & \multicolumn{5}{c}{} \\
\hline Min & $1 \mathrm{Q}$ & Median & $3 \mathrm{Q}$ & Max \\
-0.190 & -0.078 & 0.009 & 0.079 & 0.203 \\
\hline Coefficients: & Estimate & Std. Error & $\mathbf{t}$ value & $\boldsymbol{P}$-value \\
\hline (Intercept) & 0.39822 & 0.03491 & 11.406 & $7.22 \times 10^{-13} * * *$ \\
SC & 0.88604 & 0.41973 & 2.111 & $0.0404 *$ \\
Size & 0.07103 & 0.09861 & 0.720 & 0.4751 \\
Industry & -0.03282 & 0.03305 & -0.993 & 0.3260 \\
Independent Board & 0.16102 & 0.22776 & 0.707 & 0.4832 \\
Duality & 0.01742 & 0.03516 & 0.496 & 0.6226
\end{tabular}

Notes: Significant codes: $0,{ }^{* * *} 0.001, * 0.05,0.1$, and 1 . Residual standard error: 0.1073 on 45 degrees of freedom, multiple R-squared: 0.1983, adjusted R-squared: 0.1092, F statistic: 2.226 on five and 45 degrees of freedom (DF), and $p$-value: 0.06805 .

The intercept, in the model, is essentially the expected value of the risk-related disclosure quality of a company when the independent variables are considered equal to zero. In other words, the result shows that 0.401 is the unconditional expected mean of the logarithm of risk-related disclosure quality to the base 10. Therefore, it is the geometric mean of risk-related disclosure quality.

Consequently, these findings highlight that risk-related disclosure quality is influenced positively by the structural capital ( $p$-value $=0.009)$, and this clearly shows that the stated hypothesis is supported. The exponentiated coefficient is the slope of the effect of the structural capital on risk-related disclosure quality. In fact, this positive slope suggests that the presence of structural capital does raise a significant 
effect on the risk-related disclosure quality in the Italian large public interest entities. This appears to be consistent with the resource-based perspective that has been adopted as a theoretical framework of this study [57]. SC could represent the resources a company can count on for its business activity, and the $\mathrm{RDQ}$ appears to increase along with the SC. Moreover, consistently with the legitimacy theory, more structured companies appear to proactively disclose mandatory information in order to fulfill their social contract, which enables the recognition from society, and increasing the trust among investors and stakeholders.

On the other hand, other variables do not significantly influence the risk-related disclosure quality. The insignificant relationship between industry and the risk-related disclosure quality is also confirmed by Shevlin [77] and Beretta and Bozzolan [35]. Moreover, the results do not support that CG attributes (CEO duality and independent board size) have a significant effect on the risk-related disclosure quality. This result suggests that the presence of independent directors on the board and CEO duality does not raise any effect on the quality of risk-reporting in the Italian large public interest entities. This finding is in line with the results of the studies conducted by Elzahar and Hussainey [42], who also found no contributions of corporate governance in corporate risk disclosure in interim report narrative sections prepared by 72 UK companies.

\section{Conclusions}

By focusing on the disclosure of relevant information, EU Directive 2014/95/EU and its Italian transposition Legislative Decree No. 254 represent one of the initiatives intended to encourage large companies to identify and disclose their principal risks to increase trust among investors and stakeholders. While implementing SDGs, in fact, companies should also report to their stakeholders all the information about the initiatives they undertook in order to show that they "walk the talk". Of course, stakeholders would benefit from this information in their evaluation processes of firms, in understanding which risks companies have to manage in their adoption of socially responsible and sustainable behaviors and in selecting the investments that deserve trust in a forward-looking perspective, so producing positive effects on the market value and equity cost. Thus, raising concern in the determinants of risk-related disclosure is quite necessary at the moment.

Our paper contributes to existing risk-reporting literature by pioneering the examination of the role of structural capital as one of the components of intellectual capital in the risk-related disclosure quality. More specifically, the paper proposes an assessment of the disclosure quality of 51 Italian large public interest entities right after the issuance of the Legislative Decree No. 254 of December 30, 2016 on the nonfinancial disclosure CSR requirements. The degree to which the structural capital of firms affects their risk-related disclosure quality is tested. Content analysis has been used to assess the quality of the risk-related disclosure and multiple regression method to test the hypothesis.

First, the results of this study confirm that structural capital influences the risk-related disclosure quality. This provided support for our hypothesis. Results also provided some support to the positive correlation between structural capital and the firm's size. However, other control factors appear to have nonimpact on the quality of risk disclosures. These results confirm the findings of previous researchers, as well as identify a new driver of the quality of risk disclosures. By the study, it is possible to assert that firms with high levels of structural capital are expected to have better quality in disclosing their risk-related information, since they have better organizational philosophy, knowledge, and techniques in the preparation process to withstand, and even exploit, the effects of uncertainties. Indeed, intellectual capital is leveraged to reduce the perceived risks by educating the stakeholders' perceptions of risks and the company's policies to manage those risks.

To this end, this study provides some contribution to both existing risks-reporting literature and practitioners. As aforementioned, the study identifies a new driver to determine the risk-related disclosure quality. Moreover, this finding suggests that investors pay attention to structural capital in particular or intellectual capital in general while assessing the quality of the information provided. On the other hand, the company's management board is persuaded that it is necessary to improve 
their structural capital, such as the firm's procedures, processes, and internal structures, as well as organizational philosophy and techniques, in order to increase the quality of the corporate reporting.

The findings of this study provide some implications not only for the large undertakings and groups but also for small and medium-sized enterprises (SMEs). Risk-related reporting can play a relevant role in supporting the development of SMEs by decreasing the information asymmetry problem to the stakeholders, such as creditors. In addition, risk-related reporting is a powerful tool for owners and/or managers of SMEs to make adequate business decisions in terms of the allocation of resources, determining the amount of financing required, and the like. In this regard, the findings of this study persuade the company's management board to improve their structural capital, such as the firm's risk assessment procedures, risk management processes, and internal structures, as well as their organizational philosophy and techniques, in order to increase the quality of the risk-related disclosure.

The findings suggest also that the quality of the risk-related disclosure might be falling off due to the firm's limitation in SC. As a matter of fact, the statistical evidence of the positive correlation between the firm's size and SC is also documented. Smaller firms tend to have smaller SC, and vice versa. Consequently, constraints in SC, a common phenomenon in SMEs, might lead to a poor disclosure practice. Thus, SMEs should pay more attention to investing and improving SC to obtain a better disclosure quality.

Finally, this study could also be useful in the policymakers' perspective, as it provides some early evidence about the drivers that affect the risk disclosure quality of firms, with specific reference to social and environmental issues. Regulators could use these results to adjust the blueprint of the rules they issued about mandated NFI in a way to get the highest benefit for companies' information users.

Of course, our study suffers from some limitations. First, it assesses the risk-related disclosure quality scores one year right after the issuance of the decree. This data lies mainly in a short time passed by after the new regulation. Second, the analysis shares the same limitation on the linear combination assumption to qualify the disclosure with other similar studies. Third, extant literature [9,78-81] provides evidence that past cost of equity is related to nonfinancial disclosure and narratives. To measure the cost of equity, a data of analyst forecast is required; thus, further research is called to enrich the database with data about the forecasts of earnings one and two years ahead [82] and provide further evidence along this strand of research. Lastly, with the aim to generalize the findings, further research should be addressed with the data several years later or of many countries, especially for European countries, given that the new regulation is the result of a European Directive.

Author Contributions: Conceptualization, F.D.L. and A.C.; methodology, F.D.L. and H.-T.-P.P.; validation, A.C. and E.K.; data curation, H.-T.-P.P.; writing—original draft preparation, F.D.L. and H.-T.-P.P.; and writing-review and editing, A.C. and E.K. All authors have read and agreed to the published version of the manuscript.

Funding: This research received no external funding.

Acknowledgments: We appreciate comments by James Guthrie and Matti Skoog on previous drafts of this paper and from all participants at the European Conference on Intangibles and Intellectual Capital ECIIC in Pescara (Italy), in May 2019, and the Accademia Italiana di Economia Aziendale AIDEA Annual Conference in Turin (Italy) in September 2019. One of the authors (E.K.) is attending the program I.Ph.D.@UNIPG.

Conflicts of Interest: The authors declare no conflicts of interest.

\section{References}

1. Gras, D.; Conger, M.; Jenkins, A.; Gras, M. Wicked problems, reductive tendency, and the formation of (non-) opportunity beliefs. J. Bus. Ventur. 2019. [CrossRef]

2. Reinecke, J.; Ansari, S. Taming wicked problems: The role of framing in the construction of corporate social responsibility. J. Manag. Stud. 2016, 53, 299-329. [CrossRef]

3. United Nations. Global Compact. 2000. Available online: https://www.unglobalcompact.org/ (accessed on 20 December 2019).

4. United Nations. Development Goals. 2015. Available online: https://www.unglobalcompact.org/sdgs/about (accessed on 20 December 2019). 
5. Truant, E.; Corazza, L.; Scagnelli, S.D. Sustainability and Risk Disclosure: An Exploratory Study on Sustainability Reports. Sustainability 2017, 9, 636. [CrossRef]

6. Muserra, A.L.; Papa, M.; Grimaldi, F. Sustainable Development and the European Union Policy on Non-Financial Information: An Italian Empirical Analysis. Corp. Soc. Responsib. Environ. Manag. 2020, 27, 22-31. [CrossRef]

7. Caputo, F.; Leopizzi, R.; Pizzi, S.; Milone, V. The Non-Financial Reporting Harmonization in Europe: Evolutionary Pathways Related to the Transposition of the Directive 95/2014/EU within the Italian Context. Sustainability 2020, 12, 92. [CrossRef]

8. Association of Chartered Certified Accountants. Reporting Risk; Lincoln's Inn Fields: London, UK, 2014.

9. Mohamed, M.K.; Allini, A.; Ferri, L.; Zampella, A. Investors' perception on the usefulness of management report disclosures: Evidence from an emerging market. Meditari Account. Res. 2019, 27, 893-920. [CrossRef]

10. Taliento, M.; Favino, C.; Netti, A. Impact of Environmental, Social, and Governance Information on Economic Performance: Evidence of a Corporate 'Sustainability Advantage' from Europe. Sustainability 2019, 11, 1738. [CrossRef]

11. García-Sánchez, I.-M.; Hussain, N.; Martínez-Ferrero, J.; Ruiz-Barbadillo, E. Impact of disclosure and assurance quality of corporate sustainability reports on access to finance. Corp. Soc. Responsib. Environ. Manag. 2019, 26, 832-848.

12. García-Sánchez, I.M.; Gómez-Miranda, M.-E.; David, F.; Rodríguez-Ariza, L. Analyst coverage and forecast accuracy when CSR reports improve stakeholder engagement: The Global Reporting Initiative-International Finance Corporation disclosure strategy. Corp. Soc. Responsib. Environ. Manag. 2019, 26, 1392-1406. [CrossRef]

13. Campbell, J.L.; Chen, H.; Dhaliwal, D.S.; Lu, H.-m.; Steele, L.B. The information content of mandatory risk factor disclosures in corporate filings. Rev. Account. Stud. 2014, 19, 396-455. [CrossRef]

14. Elshandidy, T.; Neri, L. Corporate Governance, Risk Disclosure Practices, and Market Liquidity: Comparative Evidence from the UK and Italy. Corp. Gov. Int. Rev. 2015, 23, 331-356. [CrossRef]

15. Elshandidy, T.; Shrives, P.J. Environmental Incentives for and Usefulness of Textual Risk Reporting: Evidence from Germany. Int. J. Account. 2016, 51, 464-486. [CrossRef]

16. Moumen, N.; Othman, H.B.; Hussainey, K. The value relevance of risk disclosure in annual reports: Evidence from MENA emerging markets. Res. Int. Bus. Financ. 2015, 34, 177-204. [CrossRef]

17. Cho, C.H.; Patten, D.M. The role of environmental disclosures as tools of legitimacy: A research note. Account. Organ. Soc. 2007, 32, 639-647.

18. GRI. Linking the GRI Standards and the European Directive on Non-Financial and Diversity Disclosure. 2017. Available online: www.globalreporting.org (accessed on 29 November 2019).

19. Dobler, M.; Lajili, K.; Zéghal, D. Environmental Performance, Environmental Risk and Risk Management. Bus. Strategy Environ. 2014, 23, 1-17. [CrossRef]

20. Cho, C.H.; Laine, M.; Roberts, R.; Rodrigue, M. Organized hypocrisy, organizational façades, and sustainability reporting. Account. Organ. Soc. 2015, 40, 78-94. [CrossRef]

21. Suchman, M.C. Managing Legitimacy: Strategic and Institutional Approaches. Acad. Manag. Rev. 1995, 20, 571-610. [CrossRef]

22. Manes-Rossi, F.; Tiron-Tudor, A.; Nicolò, G.; Zanellato, G. Ensuring More Sustainable Reporting in Europe Using Non-Financial Disclosure-De Facto and De Jure Evidence. Sustainability 2018, 10, 1162. [CrossRef]

23. Roulstone, D.T. Effect of SEC Financial Reporting Release No. 48 on Derivative and Market Risk Disclosures. Account. Horiz. 1999, 343-363. [CrossRef]

24. Abraham, S.; Shrives, P.J. Improving the relevance of risk factor disclosure in corporate annual reports. Br. Account. Rev. 2014, 46, 91-107. [CrossRef]

25. Hope, O.-K.; Hu, D.; Lu, H. The benefits of specific risk-factor disclosures. Rev. Account. Stud. 2016, 21, 1005-1045. [CrossRef]

26. Gusmerotti, N.M.; Testa, F.; Macellari, M.; Frey, M. Corporate social responsibility embeddedness through a social network analysis: The case of an Italian multiutility company. Corp. Soc. Responsib. Environ. Manag. 2019. [CrossRef]

27. Cubilla-Montilla, M.I.; Galindo-Villardón, P.; Nieto-Librero, A.B.; Vicente Galindo, M.P.; García-Sánchez, I.M. What companies do not disclose about their environmental policy and what institutional pressures may do to respect. Corp. Soc. Responsib. Environ. Manag. 2019. [CrossRef] 
28. Miniaoui, Z.; Chibani, F.; Hussainey, K. The impact of country-level institutional differences on corporate social responsibility disclosure engagement. Corp. Soc. Responsib. Environ. Manag. 2019, 26, 1307-1320. [CrossRef]

29. Massingham, R.; Massingham, P.R.; Dumay, J. Improving integrated reporting: A new learning and growth perspective for the balanced scorecard. J. Intellect. Cap. 2019, 20, 60-82. [CrossRef]

30. Bontis, N.; Ciambotti, M.; Palazzi, F.; Sgro, F. Intellectual capital and financial performance in social cooperative enterprises. J. Intellect. Cap. 2018, 19, 712-731. [CrossRef]

31. Pulic, A. VAICTM-An accounting tool for IC management. Int. J. Technol. Manag. 2000, 20, 702-714. [CrossRef]

32. Bayraktaroglu, A.E.; Calisir, F.; Baskak, M. Intellectual capital and firm performance: An extended VAIC model. J. Intellect. Cap. 2019, 20, 406-425. [CrossRef]

33. Dumay, J.; Hossain, A.M. Sustainability Risk Disclosure Practices of Listed Companies in Australia. Aus. Account. Rev. 2019, 29, 343-359. [CrossRef]

34. Linsley, P.M.; Shrives, P.J. Examining risk reporting in UK public companies. J. Risk Financ. 2005, 6, $292-305$. [CrossRef]

35. Beretta, S.; Bozzolan, S. A framework for the analysis of firm risk communication. Int. J. Account. 2004, 39, 265-288. [CrossRef]

36. Linsley, P.M.; Shrives, P.J. Risk reporting: A study of risk disclosures in the annual reports of UK companies. Br. Account. Rev. 2006, 38, 387-404. [CrossRef]

37. Abraham, S.; Cox, P. Analysing the determinants of narrative risk information in UK FTSE 100 annual reports. Br. Account. Rev. 2007, 39, 227-248. [CrossRef]

38. Al-Hadi, A.; Hasan, M.M.; Habib, A. Risk Committee, Firm Life Cycle, and Market Risk Disclosures. Corp. Gov. Int. Rev. 2016, 24, 145-170. [CrossRef]

39. Marshall, A.; Weetman, P. Modelling Transparency in Disclosure: The Case of Foreign Exchange Risk Management. J. Bus. Financ. Account. 2007, 34, 705-739. [CrossRef]

40. Deumesa, R.; Knechel, W.R. Economic Incentives for Voluntary Reporting on Internal Risk Management and Control Systems. AUDIT J. Pract. Theory 2008, 27, 35-66. [CrossRef]

41. Ntim, C.G.; Lindop, S.; Thomas, D.A. Corporate governance and risk reporting in South Africa: A study of corporate risk disclosures in the pre- and post-2007/2008 global financial crisis periods. Int. Rev. Financ. Anal. 2013, 30, 363-383. [CrossRef]

42. Elzahar, H.; Hussainey, K. Determinants of narrative risk disclosures in UK interim reports. J. Risk Financ. 2012, 13, 133-147. [CrossRef]

43. Leopizzi, R.; Iazzi, A.; Venturelli, A.; Principale, S. Nonfinancial risk disclosure: The 'state of the art' of Italian companies. Corp. Soc. Responsib. Environ. Manag. 2019, 1-11. [CrossRef]

44. Rajgopal, S. Early evidence on the informativeness of the SEC's market risk disclosure: The case of commodity price risk exposure of oil and gas producers. Account. Rev. 1999, 74, 251-280. [CrossRef]

45. Elshandidy, T.; Shrives, P.J.; Bamber, M.; Abraham, S. Risk reporting: A review of the literature and implications for future research. J. Account. Lit. 2018, 40, 54-82. [CrossRef]

46. Lajili, K.; Zeghal, D. A content analysis of risk management disclosure in Canadian annual reports. Can. J. Admin. Sci. 2005, 22, 125-142. [CrossRef]

47. Lamboglia, R.; Paolone, F.; Mancini, D. Determinants of the implementation of environmental risk indicators: Empirical evidence from the Italian manufacturing context. Corp. Soc. Responsib. Environ. Manag. 2019, 26, 307-316. [CrossRef]

48. Matten, D. Strategy follows structure: Environmental risk management in commercial enterprises. Bus. Strategy Environ. 1995, 4, 107-116. [CrossRef]

49. Weinhofer, G.; Busch, T. Corporate Strategies for Managing Climate Risks. Bus. Strategy Environ. 2013, 22, 121-144. [CrossRef]

50. KPMG. The Road Ahead: The KPMG Survey of Corporate Responsibility Reporting 2017; KPMG: Amstelveen, The Netherlands, 2017.

51. Anderson, D.R.; Anderson, K.E. Sustainability risk management. Risk Manag. Ins. Rev. 2009, 12, 25-38. [CrossRef]

52. Hutton, R.; Cox, D.; Clouse, M.; Gaensbauer, J.; Banks, B. The role of sustainable development in risk assessment and management for multinational corporations. Multinatl. Bus. Rev. 2007, 15, 89-111. 
53. Bontis, N.; Keow, W.C.; Richardson, S. Intellectual capital and business performance in Malaysian industries. J. Intellect. Cap. 2000, 1, 85-100. [CrossRef]

54. Pedro, E.; Leitão, J.; Alves, H. Back to the future of intellectual capital research: A systematic literature review. Manag. Decis. 2018, 56, 2502-2583. [CrossRef]

55. Barão, A.; Silva, A.R. How to Value and Monitor the Relational Capital of Knowledge-Intensive Organizations. In Handbook of Research on Enterprise 2.0: Technological, Social, and Organizational Dimensions; Cruz-Cunha, M.M., Moreira, F., Varajão, J., Eds.; IGI Global: Hershey, PA, USA, 2014.

56. Tahat, Y.; Dunne, T.; Fifield, S.; Power, D. Risk-related disclosure: A review of the literature and an agenda for future research. Account. Forum 2019, 43, 193-219. [CrossRef]

57. Oliveira, J.; Rodrigues, L.L.; Craig, R. Voluntary risk reporting to enhance institutional and organizational legitimacy. J. Financ. Reg. Compliance 2011, 19, 271-289. [CrossRef]

58. Dowling, J.; Pfeffer, J. Organizational Legitimacy: Social Values and Organizational Behavior. Pac. Sociol. Rev. 1975, 18, 122-136. [CrossRef]

59. Mahoney, J.T.; Pandian, J.R. The resource-based view within the conversation of strategic management. Strateg. Manag. J. 1992, 13, 363-380. [CrossRef]

60. Esteve-Pérez, S.; Mañez-Castillejo, J.A. The Resource-Based Theory of the Firm and Firm Survival. Small Bus. Econ. 2008, 30, 231-249. [CrossRef]

61. Boesso, G.; Kumar, K. Drivers of corporate voluntary disclosure. A framework and empirical evidence from Italy and the United States. Account. Audit. Account. J. 2007, 20, 269-296. [CrossRef]

62. Zaman Khan, S.; Yank, Q.; Waheed, A. Investment in intangible resources and capabilities spurs sustainable competitive advantage and firm performance. Corp. Soc. Responsib. Environ. Manag. 2018, 26, 285-295. [CrossRef]

63. Cole, F. Content analysis: Process and application. Clin. Nurse Spec. 1988, 2, 53-57. [CrossRef]

64. Potter, W.; Levine-Donnerstein, D. Rethinking Validity and Reliability in Content Analysis. J. Appl. Comm. Res. 1999, 27, 258-284. [CrossRef]

65. Greco, G. The management's reaction to new mandatory risk disclosure: A longitudinal study on Italian listed companies. Corp. Comm. Int. J. 2012, 17, 113-137. [CrossRef]

66. Jain, A.; Mondal, A.; Ghosh, R. Methods and Systems for Analyzing Financial Risk Factors for Companies within an Industry. U.S. Patent Application No. 15/216,995, 25 January 2018.

67. Kazlauskienè, V.; Christauskas, C. Risk Reflection in Business Valuation Methodology. Eng. Econ. 2007, 51, 7-15.

68. Guthrie, J.; Parker, L. Corporate social disclosure practice: A comparative international analysis. Adv. Pub. Int. Account. 1990, 3, 159-175.

69. Eng, L.L.; Teo, H.K. The relation between annual report disclosures, analysts' earnings forecasts and analyst following: Evidence from Singapore. Pac. Account. Rev. 1999, 11, 219-239. [CrossRef]

70. Bozzolan, S.; Favotto, F.; Ricceri, F. Italian annual intellectual capital disclosure. J. Intellect. Cap. 2003, 4, 543-558. [CrossRef]

71. Guthrie, J.; Petty, R. Intellectual capital: Australian annual reporting practices. J. Intellect. Cap. 2000, 1, 241-251. [CrossRef]

72. Hooks, J.; Coy, D.; Howard, D. The information gap in annual reports. Account. Audit. Account. J. 2002, 4, 501-522. [CrossRef]

73. Lev, B.; Zarowin, P. The boundaries of the financial reporting and how to extend them. J. Account. Res. 1999, 2, 353-385. [CrossRef]

74. Roberts, C.; Weetman, P.; Gordon, P. International Financial Reporting: A Comparative Approach, 3rd ed.; Pearson Education Limited: Essex, UK, 2008.

75. Little T., D. Longitudinal Structural Equation Modeling (Methodology in the Social Sciences); Guilford Press: New York, NY, USA, 2013.

76. Peña, E.A.; Slate, E.H. Global Validation of Linear Model Assumptions. J. Am. Stat. Assoc. 2012, 101, $341-354$. [CrossRef]

77. Shevlin, T. Discussion of "A framework for the analysis of firm risk communication". Int. J. Account. 2004, 39, 297-302. [CrossRef]

78. Athanasakou, V.; Eugster, F.; Schleicher, T.; Walker, M. Annual Report Narratives and the Cost of Equity Capital: UK Evidence of a U-shaped Relation. Eur. Account. Rev. 2020. [CrossRef] 
79. Botosan, C.A. Disclosure level and the cost of equity capital. Account. Rev. 1997, 72, 323-349.

80. Eugster, F. Endogeneity and the Dynamics of Voluntary Disclosure Quality: Is There Really an Effect on the Cost of Equity Capital? Contemp. Account. Res. 2020. [CrossRef]

81. Lang, M.H.; Lundholm, R.J. Cross-sectional determinants of analyst ratings of corporate disclosures. J. Account. Res. 1993, 31, 246-271. [CrossRef]

82. Easton, P.D.; Monahan, S.J. An Evaluation of Accounting-Based Measures of Expected Returns. Account. Rev. 2005, 80, 501-538. [CrossRef]

(C) 2020 by the authors. Licensee MDPI, Basel, Switzerland. This article is an open access article distributed under the terms and conditions of the Creative Commons Attribution (CC BY) license (http://creativecommons.org/licenses/by/4.0/). 